\title{
Factors Confronting the Present-Day Construction Practices in South-East, Nigeria: The Professionals' View
}

\author{
Fidelis Okechukwu Ezeokoli, Chiagozie Bertrand Nonso Bert-Okonkwor, \\ MIchael Ikechukwu Okongwu, Daniel Oluwatayomi Fadumo, Christian Ifeanyi Ohaedeghasi, \\ Ngozi Marykate Okoye
}

Department of Building, Nnamdi Azikiwe University, Awka, Nigeria

Email: okeyezeokoli@gmail.com

How to cite this paper: Ezeokoli, F.O., Bert-Okonkwor, C.B.N., Okongwu, M.I., Fadumo, D.O., Ohaedeghasi, C.I. and Okoye, N.M. (2021) Factors Confronting the Present-Day Construction Practices in South-East, Nigeria: The Professionals' View. Journal of Building Construction and Planning Research, 9, 160-169. https://doi.org/10.4236/jbcpr.2021.92011

Received: February 11, 2021

Accepted: June 6, 2021

Published: June 9, 2021

Copyright $\odot 2021$ by author(s) and Scientific Research Publishing Inc. This work is licensed under the Creative Commons Attribution International License (CC BY 4.0).

http://creativecommons.org/licenses/by/4.0/

\begin{abstract}
The study evaluates the factors confronting the present-day construction practices in South-East Nigeria. Being a survey research, questionnaires containing information relating to factors/challenges affecting construction practices were randomly administered to selected construction practitioners in South-Eastern States of Nigeria. Accordingly, a total of 240 questionnaires were administered to the selected respondents while 160 copies were completed, returned and found useful. Thus, giving a response rate of $66.67 \%$. Data collected were analysed and presented using percentages, mean scores, principal and factor analysis, $z$-test and tables. The study found that the core factors that constrain present-day construction in the study area are issues related to inadequate/dearth of technical and managerial expertise, corruption and poor project planning and control; which significantly affect operational effectiveness of the construction industry in the study area. Therefore, the study concluded by recommending that thorough capacity building through training or retraining programme which should centre on areas of the issues identified should be religiously pursued in the study area.
\end{abstract}

\section{Keywords}

Construction, Present-Day Construction Practices, Construction Industry, Construction Professional, South-East Nigeria

\section{Introduction}

Construction industry in both developed and developing countries is a great contributor and/or a critical component to economic growth and development. 
As such, it serves as an indicator/litmus-paper for testing the economy of any nation. When there is upsurge in construction, one can easily infer that the economy is booming and vice versa when construction work dwindles. Consequently, construction works are employed by government as a tool for regulating economy. Also, construction industry is a great employer of labour and contributes immensely to Gross Domestic Product (GDP) of any country. Also, physical construction activities alone provide between $2 \%$ and $6 \%$ of the employment demands of the nation and the subsidiary activities provide an additional $2 \%$ to $4 \%$ in developing countries, while in the developed countries the figure rises to between $6 \%$ to $10 \%$ and $4 \%$ to $6 \%$ [1]. In Europe, construction sector for instance, over 11 million people were directly employed in the building sector, which makes it the single largest contributor to EU employment in the year 2011 [2].

Construction industry in Nigeria has achieved a great feat not only in the provision of labour and GDP but as well as the ripple effect that emanates from setting up a construction site a particular location, such as market to building/construction materials vendors, work to both skilled/unskilled/casual labourers, and market to local food sellers, to name but a few. For the past few decades, the industry continuously has witnessed tremendous change in design and construction of buildings and other civil works. As ICT accentuates the progress in the industry becomes more noticeable. The building and construction sector in Nigeria registered strong growth, standing at $12.09 \%$ in 2010 , compared to $11.97 \%$ in 2009 , reflecting greater investments in both residential and non-residential buildings and other construction activities. Growth in construction related activities rose by $12.24 \%$ in 2010 as against $11.97 \%$ in 2009 [1]. Construction contribution to the GDP ranges between 3\% and 6\% from independence to the 80 's before crumbling to about $1 \%$ over the last decades [1]. Furthermore, [1] found that the construction sector contribution to the GDP ranged between 3\% and 6\% since Nigeria gained independence until the 1980s, before decreasing to about $1 \%$ since then. While [3] observed an upward progression in the contribution of the construction industry to GDP, which was about 3\% in 2012 due to an improved budgetary implementation and private sector participation. According to [4], the sector accounted for $3.44 \%$ of real GDP in the fourth quarter 2019, lower than its contribution of $3.48 \%$ in the same quarter of the previous year, but higher than the preceding quarter's $3.01 \%$. In 2019, Construction contributed 3.72\% to real GDP. Construction sector grew by 1.31\% in Q4 2019 from 2.37\% in Q3 2019 and 2.05\% in Q4 2018. Construction sector grew by $1.81 \%$ in full year 2019 from $2.33 \%$ in 2018 and $1 \%$ in 2017 [4].

In spite of this, the construction industry in Nigeria is marred with lot of irregularities. These irregularities to [5] stem from the fact that most clients and contractors are concerned about time and cost at the expense of quality. Due to this negligence, [5] further states that "we are baptised with an industry filled with building defects and collapses." With continuous collapse of buildings, the Nigeria building industry has been the focus of attention in recent time. Also, 
clients, governments and the community are dissatisfied with the performance of the industries, and the procedures and practices they adopted. Therefore, the aim of this study is to evaluate the factors confronting the present-day construction practices in South-East Nigeria.

\section{Literature Review}

\section{Factors Affecting Construction Practice in Nigeria}

Nigeria being a developing country is confronted with a lot of problems and her construction industry is still struggling with a lot of intrinsic challenges, ranging from inadequate technical and managerial know-how to insufficient financial, material and equipment capital base [6]. According to [1] [7] the peculiar problems common to construction industries in sub-Saharan Africa (SSA) countries, are project financing, dearth of technical expertise, corrupt government and poor implementation of policies and programmes; these are challenges mitigating the development and growth of the sector and hence the contribution to the sustainable development. Other problems of local companies revolve around executive capacity and critical mass with technical and financial wherewithal. Generally, most local companies are small, fragmented and incapable of packaging or attracting loans. Few of them can deliver turnkey projects without resorting to some form of partnership agreement for equipment, expertise or technical support.

Balouga [7] observed that there exists the so-called "Knowing-Doing gap" in Nigeria, that is the disconnect that exists between policy formulation and policy implementation. This term describes the absence of a critical link between strategy and action. Public policy initiatives and actions in Nigeria have persistently been incapacitated by this gap, with many government programmes and projects ending in downright failure. Inadequate think through, weak institutional capacity, lack of political will to carry through change, inconsistency in government policies, lack of support from relevant stakeholders and corruption are some of the causes of this gap.

To [8], the high operating cost obtainable in the construction industry which result in low profit margins has also created tax challenges for the companies as they have been unable to fully utilize opportunities for relief available under the provisions of the tax Laws. The constant challenge in this industry is that Project Owners usually deduct tax at $5 \%$ from the entire contract sum instead of withholding only on the required percentage of the profits accruing to the Counter-party companies. Given that construction companies typically operate at low margins, they are in perpetual tax refund position. This also has significant impact for their cashflow position. In addition, there is that perennial challenge for construction companies to claim input VAT.

On the other hand, [9] studied Construction Industry and its Constraints in Nigeria using structured questionnaire administered to construction professionals and contractors in Imo State and observed that factors affecting construction 
industry in Nigeria are scope creep, inadequate funding, poor quality control, constant rising of project costs, lack of skilled labour, abandoned projects, corruption issues, safety on site, capital supply constraints. However, the study observed that corruption, inadequate funding and constant rising of project costs are core issues. Based on this, the study concluded that constraints in the Nigerian construction industry, are nothing but greed, corruption, unpatriotic, unprofessional and political misfortune. In this country, construction is all comers' affair, no standard, no regulation or code, no adequate planning and sincere monitoring of projects. Government agencies' trust with construction project development lacks the honesty and technical proficiency to manage such projects.

Similarly, [10] using field survey and interview examined participation of indigenous contractors in Nigerian public sector construction projects and their challenges in managing working capital. The study centers on indigenous construction firms of not less than five years practical experience, executing public construction projects in Imo state Nigeria. Accordingly, The study observed that Low awareness of the need for working capital management; One-man business setbacks such as: poor technical skills, inadequate manpower, absence of corporate organization; undercapitalization; poor funding and cash flow problems; high cost of construction finance; economic recession; indiscipline and reckless spending by indigenous contractors, diversion of contract funds for uses other than the project; Poor project planning and control; inflation in prices of construction resources; delays in interim payments and settlement of claims for variations, fluctuations, loss and expense; taxation at source (withholding tax and VAT); and Deduction of retention fund were factors confronting indigenous contractors in Nigerian public sector construction projects.

Furthermore, [7] [11] observed that while most other industries have undergone tremendous changes over the past few decades, and have reaped the benefits of process, product and service innovations, the construction sector which often is one of the key sectors of any economy has been traditionally slow at technological development. Because of this, its labour productivity has stagnated or even decreased over the years. Similarly [12]-[17] observed that the construction and real estate sector in Nigeria ranks lowest in terms of digital maturity (i.e. Industry lags behind other industries in using ICT).

Consequently, the mediocre track record attributed to various internal and external challenges in Nigerian Construction Industry coupled with the persistent fragmentation of the industry; inadequate collaboration between the players; the sector's difficulty in adopting and adapting to new technologies; the difficulties in recruiting a talented and future-ready workforce have continuously shown that the future of the Nigerian construction industry will be dominated or controlled by foreigners if nothing is done to reverse the trend [7].

\section{Methodology}

This study was carried out in south east, Nigeria. South East Nigeria is made of 5 
states, namely: Abia, Anambra, Ebonyi, Enugu and Imo. Basically, data for this study were sourced from construction stakeholders from the major cities within the south east geopolitical zone of Nigeria. The population of this study consist of all duly registered construction professionals residing and practicing within the study area. These professionals include Architects, Builders, Civil Engineers, Quantity surveyors and Estate surveyor and valuers. Also, the study adopted purposive and multi-stage sampling techniques for the choice of individual selected for the interview and questionnaires distribution respectively. Questionnaire, direct observation, interviews, focus group discussion and review of existing literature on construction industry recommended by previous researchers were used as data collection instruments. Accordingly, a total of 240 questionnaires were distributed. From each state, the questionnaires were administered to eight (8) of these listed professionals, totally 48 each. However, 160 questionnaires were duly filled and returned. These correspond to response rate of $66.67 \%$ (see Table 1). Data obtained was analyzed using charts, table of frequency, mean scores, principal component and factor test analysis and z-test for questionnaire. Furthermore, the data analysis was facilitated by a computer database software packages-Statistical Package for the Social Sciences (SPSS) Statistic.

\section{Results}

In the descriptive statistics result in Table 2, the outlisted are factors affecting construction practices $($ mean $=3.61>3.00$ ). From the results in Table 2 , the respondents disagree on the practice of low profit margins ( mean $=2.38<3.00$ ), poor project planning and quality control (mean $=2.88<3.00$ ), lack of skilled labour (mean $=2.50<3.00$ ). However, the corruption issues are the major factors affecting construction practices in Nigeria (mean $=4.50)$. The second in ranking are project finance/capital supply constraints (mean $=4.25$ ), and inflation in prices of construction resources (mean $=4.25)$.

To further reduce the number of factors affecting construction practices in Nigeria and at the same time recruit any essential unrecruited ones, the research employed inferential statistical technique, the principal component method of factor analysis. Before the principal component analysis, proper, test of interdependence (correlation) was performed. The result of the analysis was presented in Table 3.

The rest of test of interdependence among the factors revealed that they are highly correlated (with about $60 \%$ of partial correlation coefficient $\left(r_{i}\right) \geq 0.50$ ), which indicates interdependence and explicitly, the presence of autocorrelation

Table 1. Distribution of questionnaire and percentage response.

\begin{tabular}{ccc}
\hline Questionnaires & Frequency & Percentage (\%) \\
\hline Number of questionnaires returned & 160 & 66.67 \\
Number of questionnaires not returned & 80 & 33.33 \\
TOTAL & 240 & 100 \\
\hline
\end{tabular}


Table 2. Factors affecting construction practices in Nigeria.

\begin{tabular}{|c|c|c|c|c|c|c|c|c|c|}
\hline Factors affecting construction practices & 5 & 4 & 3 & 2 & 1 & $W_{i} X_{i}$ & $\sum f$ & Mean $(\bar{X})$ & Remark \\
\hline $\begin{array}{l}\text { Inadequate/dearth of technical or } \\
\text { managerial expertise }\end{array}$ & 40 & 60 & 20 & 20 & 20 & 560 & 160 & 3.50 & Agree \\
\hline Project finance/capital supply constraints & 80 & 40 & 40 & 0 & 0 & 680 & 160 & 4.25 & Agree \\
\hline Corruption issues & 120 & 0 & 40 & 0 & 0 & 720 & 160 & 4.50 & Agree \\
\hline Fragmented nature of the industry & 60 & 40 & 60 & 20 & 0 & 680 & 180 & 3.78 & Agree \\
\hline Incapable of packaging or attracting loans & 40 & 60 & 60 & 0 & 0 & 620 & 160 & 3.88 & Agree \\
\hline $\begin{array}{l}\text { Disconnection of policy formulation } \\
\text { and policy implementation }\end{array}$ & 80 & 20 & 60 & 0 & 0 & 660 & 160 & 4.13 & Agree \\
\hline Low profit margins & 0 & 0 & 100 & 20 & 40 & 380 & 160 & 2.38 & Disagree \\
\hline $\begin{array}{l}\text { High operating costs/constant rising } \\
\text { of project costs }\end{array}$ & 0 & 80 & 60 & 20 & 0 & 540 & 160 & 3.38 & Agree \\
\hline Scope creep & 20 & 20 & 80 & 40 & 0 & 500 & 160 & 3.13 & Agree \\
\hline Inadequate funding & 40 & 60 & 60 & 0 & 0 & 620 & 160 & 3.88 & Agree \\
\hline Poor project planning \& quality control & 0 & 40 & 80 & 20 & 20 & 460 & 160 & 2.88 & Disagree \\
\hline Lack of skilled labour & 0 & 60 & 20 & 20 & 60 & 400 & 160 & 2.50 & Disagree \\
\hline Abandoned projects & 20 & 40 & 80 & 20 & 0 & 540 & 160 & 3.38 & Agree \\
\hline Safety on site & 40 & 20 & 60 & 40 & 0 & 540 & 160 & 3.38 & Agree \\
\hline Inflation in prices of construction resources & 60 & 80 & 20 & 0 & 0 & 680 & 160 & 4.25 & Agree \\
\hline $\begin{array}{l}\text { Slow pace of technological } \\
\text { development/difficulty in adopting and } \\
\text { adapting to new technologies }\end{array}$ & 60 & 40 & 60 & 0 & 0 & 640 & 160 & 4.00 & Agree \\
\hline Economic recession & 40 & 80 & 20 & 20 & 0 & 620 & 160 & 3.88 & Agree \\
\hline $\begin{array}{l}\text { Inadequate collaboration between } \\
\text { the players }\end{array}$ & 40 & 60 & 60 & 0 & 0 & 620 & 160 & 3.88 & Agree \\
\hline Cluster mean & & & & & & & & 3.61 & Agree \\
\hline
\end{tabular}

Note: 5 = SA = Strongly Agree; 4 = A = Agree; 3 = Undecided; 2 = D = Disagree; $1=\mathrm{SD}=$ Strongly Disagree.

problem. This confirms appropriateness of reduction statistics (factor analysis) to sieve out the nuisance and retain the latent factors affecting construction practices in Nigeria. The factor analysis result (Principal component method) was presented in Table 4.

From the Principal Component Analysis (PCA) result in Table 4, the 18 outlisted factors affecting construction practices in Nigeria were reduced to 3 which collectively accounted for about $95.7 \%$ of the total variations in the challenges confronting construction industry in Nigeria. Particularly, these factors extracted (which have eigenvalues $>1.0$ ) include: Inadequate/dearth of technical or managerial expertise (52.041\%), corruption issues (24.101\%), and poor project planning \& quality control (19.561\%). Therefore, the key factors affecting present-day construction practices in the study area are issues related to inadequate/dearth of technical and managerial expertise, corruption and poor project 
Table 3. Correlation matrix of test of interdependence.

\begin{tabular}{|c|c|c|c|c|c|c|c|c|c|c|c|c|c|c|c|c|c|c|}
\hline & $\vec{x}$ & $\tilde{x}$ & $\ddot{x}$ & $\ddot{\star}$ & $\ddot{x}$ & $\ddot{\not}$ & $\hat{x}$ & $\mathscr{\varnothing}$ & $\widehat{x}$ & $\stackrel{\circ}{\ddot{x}}$ & $\overrightarrow{\vec{x}}$ & $\tilde{x}$ & $\stackrel{m}{\vec{x}}$ & $\overrightarrow{\vec{x}}$ & $\vec{n}$ & $\stackrel{\mathscr{A}}{\not}$ & $\overrightarrow{\vec{x}}$ & $\stackrel{\infty}{\not{x}}$ \\
\hline$\vec{x}$ & $\underset{-}{\stackrel{8}{ }}$ & & & & & & & & & & & & & & & & & \\
\hline$\ddot{x}$ & $\begin{array}{l}n \\
\stackrel{n}{n} \\
0\end{array}$ & $\underset{-}{\stackrel{8}{\circ}}$ & & & & & & & & & & & & & & & & \\
\hline$\ddot{x}$ & $\underset{\stackrel{)}{I}}{\stackrel{0}{0}}$ & $\underset{\substack{1 \\
0 \\
0}}{ }$ & $\underset{-}{\stackrel{8}{\circ}}$ & & & & & & & & & & & & & & & \\
\hline$\ddot{x}$ & $\stackrel{m}{\tilde{H}}$ & 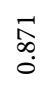 & $\begin{array}{l}\stackrel{2}{1} \\
\vdots\end{array}$ & $\stackrel{8}{-}$ & & & & & & & & & & & & & & \\
\hline$\ddot{x}$ & $\begin{array}{l}\text { مू } \\
\text { in } \\
0\end{array}$ & $\begin{array}{l}\stackrel{2}{\hat{O}} \\
\text { ó }\end{array}$ & ঐે & $\begin{array}{l}H \\
\infty \\
0 \\
0\end{array}$ & $\underset{-}{\stackrel{\leftrightarrow}{\circ}}$ & & & & & & & & & & & & & \\
\hline$\ddot{\not}$ & $\begin{array}{l}n \\
\infty \\
0 \\
0\end{array}$ & $\begin{array}{l}\vec{\sigma} \\
\text { ô }\end{array}$ & $\begin{array}{l}\infty \\
\stackrel{0}{\circ} \\
0\end{array}$ & \begin{tabular}{l}
$\infty$ \\
\multirow{2}{0}{} \\
0
\end{tabular} & $\begin{array}{l}n \\
\tilde{n} \\
0 \\
0\end{array}$ & 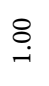 & & & & & & & & & & & & \\
\hline$\hat{x}$ & $\begin{array}{l}\text { fै } \\
\text { í } \\
\text { i }\end{array}$ & $\begin{array}{l}\text { ⿵̃ } \\
\text { ஸ̂ } \\
\text { î }\end{array}$ & $\begin{array}{c}\text { ते } \\
\text { i } \\
i\end{array}$ & 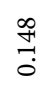 & $\begin{array}{l}\stackrel{2}{2} \\
\stackrel{0}{0}\end{array}$ & $\begin{array}{l}\stackrel{D}{ \pm} \\
\stackrel{0}{0}\end{array}$ & $\underset{-}{\stackrel{8}{ }}$ & & & & & & & & & & & \\
\hline$\ddot{x}$ & ণั & $\begin{array}{l}\text { oे } \\
\text {. }\end{array}$ & $\begin{array}{l}\stackrel{0}{\hat{m}} \\
\hat{m} \\
i\end{array}$ & 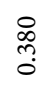 & $\begin{array}{l}\stackrel{H}{t} \\
\stackrel{5}{0}\end{array}$ & $\begin{array}{l}n \\
0 \\
0 \\
0\end{array}$ & $\underset{\sim}{\stackrel{1}{0}}$ & $\stackrel{\text { ¿ }}{\circ}$ & & & & & & & & & & \\
\hline$\ddot{x}$ & $\begin{array}{c}\tilde{N} \\
\tilde{n} \\
\stackrel{1}{1}\end{array}$ & $\stackrel{\infty}{\leftrightarrows}$ & $\begin{array}{l}0 \\
0 \\
0 \\
0\end{array}$ & $\begin{array}{l}\text { OD } \\
\text { గn } \\
0\end{array}$ & 㟧 & $\begin{array}{l}\vec{\infty} \\
\stackrel{0}{0}\end{array}$ & $\begin{array}{l}\vec{n} \\
\hat{0}\end{array}$ & $\underset{+}{\stackrel{N}{+}}$ & $\underset{-}{\stackrel{8}{0}}$ & & & & & & & & & \\
\hline$\stackrel{\circ}{\vec{x}}$ & $\begin{array}{l}\text { مे } \\
\text { ஸे } \\
0\end{array}$ & $\begin{array}{l}\stackrel{2}{2} \\
\text { o }\end{array}$ & $\underset{\text { ते }}{\stackrel{0}{0}}$ & $\begin{array}{l}\stackrel{+}{\infty} \\
\infty \\
0\end{array}$ & $\stackrel{8}{\stackrel{-}{-}}$ & $\begin{array}{l}n \\
\hat{b} \\
0\end{array}$ & 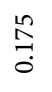 & $\frac{\mathbb{H}}{\stackrel{H}{0}}$ & 尔 & $\stackrel{8}{-}$ & & & & & & & & \\
\hline $\overrightarrow{\vec{x}}$ & $\begin{array}{l}\text { 辛 } \\
\stackrel{+}{0}\end{array}$ & $\begin{array}{l}\hat{\imath} \\
\hat{0} \\
0 \\
i\end{array}$ & $\begin{array}{l}m \\
0 \\
0 \\
i \\
i\end{array}$ & ָి & 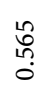 & $\begin{array}{l}\stackrel{\circ}{0} \\
\stackrel{0}{0}\end{array}$ & $\begin{array}{l}\vec{\sigma} \\
0 \\
0\end{array}$ & $\frac{\mathbb{H}}{\stackrel{J}{0}}$ & $\begin{array}{l}\stackrel{\infty}{\infty} \\
\stackrel{0}{0}\end{array}$ & 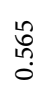 & $\underset{-}{\stackrel{8}{0}}$ & & & & & & & \\
\hline$\tilde{x}$ & 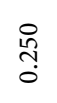 & $\begin{array}{l}n \\
\hat{n} \\
\hat{n} \\
i \\
i\end{array}$ & $\underset{\substack{N \\
i}}{\stackrel{N}{i}}$ & $\begin{array}{l}\text { స్రి } \\
\text { i }\end{array}$ & $\begin{array}{l}\infty \\
\stackrel{0}{0} \\
0 \\
i\end{array}$ & $\begin{array}{l}\infty \\
\stackrel{0}{0} \\
\stackrel{0}{0}\end{array}$ & $\begin{array}{l}\text { Na } \\
\text { Oे } \\
\text { i }\end{array}$ & $\stackrel{\infty}{\sim}$ & $\begin{array}{l}\hat{O} \\
\stackrel{1}{0} \\
\stackrel{0}{1}\end{array}$ & $\begin{array}{l}\infty \\
\stackrel{0}{0} \\
\stackrel{+}{1}\end{array}$ & $\stackrel{f}{\stackrel{+}{\circ}}$ & $\stackrel{\circ}{\circ}$ & & & & & & \\
\hline$\stackrel{m}{\vec{x}}$ & $\hat{\tilde{o}}$ & 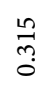 & $\begin{array}{l}\circ \\
\vdots \\
0\end{array}$ & $\begin{array}{l}\infty \\
\stackrel{2}{2} \\
0\end{array}$ & 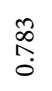 & $\stackrel{N}{\stackrel{N}{0}}$ & \begin{tabular}{l}
$\mathbb{N}$ \\
\multirow{6}{0}{} \\
0
\end{tabular} & $\begin{array}{l}\stackrel{H}{*} \\
\stackrel{0}{0}\end{array}$ & $\begin{array}{l}\vec{a} \\
0 \\
0\end{array}$ & $\begin{array}{l}\infty \\
\stackrel{0}{0} \\
0\end{array}$ & $\begin{array}{l}\vec{a} \\
\dot{0} \\
\dot{0}\end{array}$ & $\begin{array}{l}\vec{N} \\
\stackrel{i}{0} \\
1\end{array}$ & $\underset{-}{\stackrel{-}{\prime}}$ & & & & & \\
\hline$\vec{\Delta}$ & $\begin{array}{l}2 \\
\stackrel{0}{0} \\
1\end{array}$ & 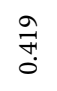 & 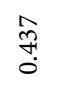 & 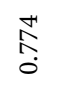 & $\begin{array}{l}\text { Oo. } \\
\stackrel{0}{0} \\
0\end{array}$ & $\begin{array}{l}\stackrel{\infty}{0} \\
\stackrel{W}{0} \\
0\end{array}$ & $\begin{array}{l}\mathbb{H} \\
\stackrel{H}{0}\end{array}$ & $\begin{array}{l}\stackrel{0}{0} \\
\text { ஸे }\end{array}$ & $\begin{array}{l}\circ \\
\stackrel{0}{0} \\
0\end{array}$ & $\begin{array}{l}\text { } \\
\stackrel{0}{0} \\
0\end{array}$ & $\begin{array}{l}\hat{0} \\
\stackrel{0}{0} \\
0\end{array}$ & $\begin{array}{l}\stackrel{+}{\infty} \\
\stackrel{0}{0} \\
i\end{array}$ & $\begin{array}{l}\stackrel{N}{\Omega} \\
0 \\
0\end{array}$ & $\underset{-}{\stackrel{8}{ }}$ & & & & \\
\hline$\vec{n}$ & 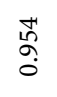 & $\begin{array}{l}\hat{n} \\
\stackrel{2}{0} \\
0\end{array}$ & $\begin{array}{l}\infty \\
\stackrel{\infty}{0} \\
0\end{array}$ & $\begin{array}{l}\vec{\sigma} \\
0 \\
0\end{array}$ & $\begin{array}{l}\underset{+}{*} \\
\stackrel{0}{0}\end{array}$ & $\underset{\stackrel{R}{+}}{\stackrel{0}{0}}$ & $\begin{array}{l}\infty \\
\vec{n} \\
0 \\
1\end{array}$ & $\underset{\substack{\stackrel{2}{f} \\
0}}{ }$ & $\begin{array}{l}\tilde{0} \\
\stackrel{-1}{0} \\
1\end{array}$ & $\begin{array}{l}\mathbb{H} \\
\stackrel{H}{0}\end{array}$ & $\begin{array}{l}\hat{\hat{O}} \\
0 \\
0\end{array}$ & $\begin{array}{l}\overrightarrow{\tilde{O}} \\
\dot{0}\end{array}$ & ํㅗㅇ & $\begin{array}{l}\stackrel{H}{0} \\
0 \\
0\end{array}$ & $\underset{-}{\stackrel{-}{~}}$ & & & \\
\hline$\stackrel{\mathscr{A}}{\not}$ & $\begin{array}{l}\text { 용 } \\
\stackrel{+}{0}\end{array}$ & $\begin{array}{l}\text { ڤ̊ } \\
\text { م. }\end{array}$ & $\begin{array}{l}\infty \\
\stackrel{2}{R} \\
0\end{array}$ & $\begin{array}{l}\overrightarrow{0} \\
\text { o }\end{array}$ & $\begin{array}{l}\vec{\sigma} \\
0 \\
0\end{array}$ & $\begin{array}{l}0 \\
\text { م̆ } \\
0\end{array}$ & $\stackrel{\substack{n \\
0}}{-!}$ & 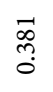 & 黛 & $\begin{array}{l}\vec{a} \\
\stackrel{0}{0}\end{array}$ & 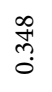 & $\begin{array}{l}\hat{O} \\
\stackrel{1}{0} \\
i\end{array}$ & $\begin{array}{l}\frac{1}{6} \\
0 \\
0\end{array}$ & \begin{tabular}{l}
1 \\
\multirow{0}{0}{} \\
0
\end{tabular} & $\begin{array}{l}n \\
\hat{L} \\
0\end{array}$ & $\stackrel{8}{-}$ & & \\
\hline$\hat{\vec{x}}$ & 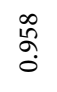 & $\underset{\mathfrak{n}}{\stackrel{n}{0}}$ & 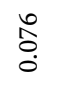 & \begin{tabular}{l}
$n$ \\
\multirow{2}{2}{} \\
0 \\
0
\end{tabular} & \begin{tabular}{l}
\multirow{H}{0}{} \\
$\stackrel{0}{0}$
\end{tabular} & $\begin{array}{l}\stackrel{\overbrace{}}{1} \\
0\end{array}$ & $\begin{array}{l}7 \\
\text { ñ } \\
0 \\
1\end{array}$ & $\begin{array}{l}\tilde{L} \\
0 \\
0\end{array}$ & $\begin{array}{l}\hat{\infty} \\
0 \\
0 \\
i\end{array}$ & $\begin{array}{l}\frac{\pi}{6} \\
0 \\
0\end{array}$ & $\begin{array}{l}\tilde{\Xi} \\
\stackrel{0}{0}\end{array}$ & $\underset{+}{\stackrel{+}{+}}$ & $\underset{\widetilde{\jmath}}{\tilde{0}}$ & $\begin{array}{l}\text { ¿े. } \\
\text { ல }\end{array}$ & $\begin{array}{l}\stackrel{0}{ } \\
\text { مे } \\
\text { o }\end{array}$ & 㔯 & $\stackrel{\circ}{\circ}$ & \\
\hline$\stackrel{\infty}{\not \vec{x}}$ & $\begin{array}{l}8 \\
\text { ñ? } \\
0\end{array}$ & $\begin{array}{l}\stackrel{2}{\stackrel{2}{0}} \\
\text { o. }\end{array}$ & స్ & $\begin{array}{l}\stackrel{H}{ } \\
\infty \\
0 \\
0\end{array}$ & $\stackrel{\leftrightarrow}{\stackrel{-}{-}}$ & $\begin{array}{l}\tilde{\Omega} \\
\stackrel{0}{0} \\
0\end{array}$ & $\begin{array}{l}\stackrel{n}{\Lambda} \\
\stackrel{0}{0}\end{array}$ & 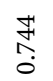 & 点 & $\underset{-}{\stackrel{8}{ }}$ & 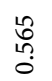 & $\begin{array}{l}\infty \\
0 \\
0 \\
0\end{array}$ & $\begin{array}{l}\stackrel{\infty}{\infty} \\
\stackrel{0}{0}\end{array}$ & $\begin{array}{l}\tilde{0} \\
\stackrel{0}{0} \\
0\end{array}$ & $\begin{array}{l}\stackrel{H}{N} \\
0 \\
0\end{array}$ & $\begin{array}{l}\vec{\partial} \\
\infty \\
0 \\
0\end{array}$ & \begin{tabular}{l}
+1 \\
\multirow{6}{0}{} \\
0
\end{tabular} & $\stackrel{\text { : }}{\circ}$ \\
\hline
\end{tabular}

a. This matrix is not positive definite. where, $\mathrm{X}_{1}=$ Inadequate/dearth of technical or managerial expertise; $\mathrm{X}_{2}=$ Project finance/Capital supply constraints; $\mathrm{X}_{3}=$ Corruption issues; $\mathrm{X}_{4}=$ Fragmented nature of the industry; $\mathrm{X}_{5}=$ Incapable of packaging or attracting loans; $\mathrm{X}_{6}=$ Disconnection of policy formulation and policy implementation; $\mathrm{X}_{7}=$ Low profit margins; $\mathrm{X}_{8}=$ High operating costs/constant rising of project costs; $\mathrm{X}_{9}=$ Scope creep; $\mathrm{X}_{10}=$ Inadequate funding; $\mathrm{X}_{11}=$ Poor Project planning \& quality control; $\mathrm{X}_{12}=$ Lack of skilled labour; $\mathrm{X}_{13}=$ Abandoned projects; $\mathrm{X}_{14}=$ Safety on site; $\mathrm{X}_{15}=$ Inflation in prices of construction resources; $\mathrm{X}_{16}=$ Slow pace of technological development/difficulty in adopting and adapting to new technologies; $\mathrm{X}_{17}=$ Economic recession; $\mathrm{X}_{18}=$ Inadequate collaboration between the players. 
Table 4. Result of factor analysis (rotated component matrix) and factor loadings.

\begin{tabular}{|c|c|c|c|c|}
\hline \multirow{2}{*}{ Factors } & \multicolumn{3}{|c|}{ Component } & \multirow{2}{*}{$\%$ age extracted } \\
\hline & 1 & 2 & 3 & \\
\hline Inadequate/dearth of technical or managerial expertise & 0.956 & -0.005 & -0.282 & 0.992 \\
\hline Project finance/Capital supply constraints & 0.563 & 0.815 & -0.044 & 0.983 \\
\hline Corruption issues & 0.099 & 0.965 & -0.187 & 0.976 \\
\hline Fragmented nature of the industry & 0.477 & 0.774 & 0.409 & 0.994 \\
\hline Incapable of packaging or attracting loans & 0.781 & 0.340 & 0.510 & 0.985 \\
\hline Disconnection of policy formulation and policy implementation & 0.276 & 0.918 & 0.199 & 0.959 \\
\hline Low profit margins & -0.394 & 0.017 & 0.853 & 0.884 \\
\hline High operating costs/constant rising of project costs & 0.687 & -0.290 & 0.643 & 0.969 \\
\hline Scope creep, & -0.102 & 0.307 & 0.909 & 0.930 \\
\hline Inadequate funding & 0.781 & 0.340 & 0.510 & 0.985 \\
\hline Poor project planning \& quality control & 0.142 & -0.162 & 0.968 & 0.984 \\
\hline Lack of skilled labour & 0.264 & -0.897 & -0.081 & 0.881 \\
\hline Abandoned projects & 0.307 & 0.234 & 0.921 & 0.997 \\
\hline Safety on site & -0.048 & 0.647 & 0.646 & 0.837 \\
\hline Inflation in prices of construction resources & 0.949 & 0.266 & -0.167 & 10.000 \\
\hline $\begin{array}{l}\text { Slow pace of technological development/difficulty in adopting and } \\
\text { adapting to new technologies }\end{array}$ & 0.555 & 0.720 & 0.374 & 0.967 \\
\hline Economic recession & 0.954 & 0.012 & -0.077 & 0.916 \\
\hline Inadequate collaboration between the players & 0.781 & 0.340 & 0.510 & 0.985 \\
\hline Eigenvalue & 9.367 & 4.338 & 3.521 & \\
\hline$\%$ age of variance & 52.041 & 24.101 & 19.561 & \\
\hline Cumulative \% age & 52.041 & 76.142 & 95.702 & \\
\hline
\end{tabular}

Extraction method: principal component analysis. Rotation method: Varimax with Kaiser normalization. a. Rotation converged in 5 iterations.

Table 5. Hypothetical statement.

\begin{tabular}{ccc} 
Hypothetical statement & Test statistic & Result \\
\hline $\begin{array}{c}\text { The challenges to Nigerian construction practices do not significantly decide the } \\
\text { operational effectiveness of construction projects in Nigeria }\end{array}$ & z-test & $4.336 ; \mathrm{p}=0.000<0.05$ \\
\hline
\end{tabular}

Source: Author's SPSS 25.0 computation. Inferentially, the identified challenges to construction practices in Nigeria significantly determine operational effectiveness of the construction industry $(4.336 ; \mathrm{p}=0.000<0.05)$.

planning and control.

Conversely, in order to confirm if these outlisted factors in Tables 2-4 affect operational effectiveness of the construction industry in study. Therefore, a hypothetical statement was proposed and tested using z-test. The result of the analysis is presented in Table 5.

\section{Conclusion}

To successfully complete a project, the product has to meet the expected level of quality and contract terms. The project environment and system of work have to 
be integrated and aligned so as to enable the people to perform their work efficiently, effectively, and safely. Unfortunately, lots of factors constrain effective performances of construction projects in present-day Nigeria. Also, it is of no doubt that unethical practices have found their way to the construction industry and they have significantly not improved the industry both in the area of service and project delivery. On this note the study was conceived and the study revealed lots of factors that constrain present-day construction in the study area. However, the core factors are issues related to inadequate/dearth of technical and managerial expertise, corruption and poor project planning and control; which significantly affect operational effectiveness of the construction industry in the study area. Therefore, efforts should be made to address the identified core problems in the study area. Government, various construction professional bodies, schools/universities and construction firms in the study area should embark on thorough capacity building through training or retraining programme which should center on areas of the issues identified and the danger it poses to the future of the industry in Nigeria.

\section{Acknowledgements}

The authors wish to express their most sincere gratitude to the duly registered construction professionals residing and practicing within the study area (these professionals include Architects, Builders, Civil Engineers, Quantity surveyors and Estate surveyors and valuers) for finding time to respond to the questionnaire, despite their busy schedule.

\section{Conflicts of Interest}

The authors declare no conflicts of interest regarding the publication of this paper.

\section{References}

[1] Isa, R.B., Jimoh, R.A. and Achenu, E. (2013) An Overview of the Contribution of Construction Sector to Sustainable Development in Nigeria. Net Journal of Business Management, 1, 1-6.

[2] Groote, M.D. and Lefver, M. (2016) Driving Transformation Change in the Construction Value Chain. Building Performance Institute Europe (BPIE).

[3] Okoye, P.U., Mbakwe, C.C. and Igbo, E.N. (2018) Modelling the Construction Sector and Oil Prices towards Growth of Nigerian Economy: An Econometric Approach. Economies, 6, 1-19. https://doi.org/10.3390/economies6010016

[4] National Bureau of Statistics (NBS) Nigerian Construction Sector. First Quarter Report, 2019. https://www.nigerianstat.gov.ng/

[5] Obiegbu, M.E. and Ezeokoli, F.O. (2014) Building Information Modelling (BIM), a Panacea for Timely Project Delivery. Being a Paper Delivered at River State Quantity Surveyor's Week, Holding at the Arena Event Centre, Tombia Street, Port Harcourt, Nigeria.

[6] Ezeokoli, F.O., Ugochukwu, S.C. Agu, N.N. and Akabougu, S.C. (2016) An Assessment of the Use, Benefits and Challenges of the "Cash-Lite" Policy, for Construc- 
tion Projects in Anambra State, Nigeria. European Scientific Journal, 12, 313-328. https://doi.org/10.19044/esj.2016.v12n16p313

[7] Balouga, J. (2012) Nigerian Local Content: Challenges and Prospects. International Association for Energy Economics, Third Quarter, 23-26.

[8] Oluseye, A. and Fatai, F. (2015) Fiscal Challenges in the Construction Sector in Nigeria: Is Any Relief in Sight? Inside Tax, Proceeding of 2 Day Seminar Deloitte on Employees \& Executive Compensation Planning, Port Harcourt, 5-6 February 2015. https://www2.deloitte.com/content/dam/Deloitte/ng/Documents/tax/inside-tax/ngfiscal-challenges-in-the-construction-sector-in-nigeria.pdf

[9] Iheme, C.C. and Chiagorom, C.F. (2018) Construction Industry and Its Constraints in Nigeria. International Journal of Advanced Research in Social Engineering and Development Strategies, 5, 44-53.

[10] Ugochukwu, S.C. and Onyekwena, T. (2014) Participation of Indigenous Contractors in Nigerian Public Sector Construction Projects and Their Challenges in Managing Working Capital. International Journal of Civil Engineering, Construction and Estate Management, 1, 1-21.

[11] Ezeokoli, F.O., Okolie, K.C., Okoye, P.U. and Belonwu, C.C. (2016) Digital Transformation in the Nigeria Construction Industry: The Professionals' View. World Journal of Computer Application and Technology, 4, 23-30. https://doi.org/10.13189/wjcat.2016.040301

[12] Ezeokoli, F.O., Okoye, P.U. and Nkeleme, E.I. (2016) Factors Affecting the Adaptability of Building Information Modelling (BIM) for Construction Projects in Anambra State Nigeria. Journal of Scientific Research \& Reports, 11, 1-10. https://doi.org/10.9734/ISRR/2016/26563

[13] Ezeokoli, F.O., Onyia, C.I. and Bert-Okonkwo, C.B.N. (2019) State of Readiness of Nigerian Construction Industry towards Digital Transformation: The Construction Professionals' Perception. Journal of Engineering Research and Reports, 4, 1-11. https://doi.org/10.9734/jerr/2019/v4i216896

[14] Kane, G.C., Palmer, D., Phillips, A.N., Kiron, D. and Buckley, N. (2015) Strategy, Not Technology, Drives Digital Transformation Becoming a Digitally Mature Enterprise, MIT Sloan Management Review Articles. http://www.sloanreview.mit.edu

[15] Africa Practice. The Social Media Landscape in Nigeria: The Ho, the What and the How, 2014. http://www.africapractice.com

[16] Oladapo, A.A. (2007) An Investigation into the Use of ICT in the Nigerian Construction Industry. ITcon Journal, 12, 261-277.

[17] Kelly, H. (1984) Technology and the Construction Industry: An Introduction. The AIA Press, Washington DC. 